\title{
Characterization and Genetic Relationships of Wild Species and Old Garden Roses Based on Microsatellite Analysis
}

\author{
Valentina Scariot ${ }^{1}$, Aziz Akkak ${ }^{2}$, and Roberto Botta ${ }^{2}$ \\ Università degli Studi di Torino, Via Leonardo da Vinci 44, 10095 Grugliasco (TO), Italy
}

\begin{abstract}
AdDITIONAL INDEX wORDs. Rosa, DNA, SSR, STMS, molecular markers, allelic phenotype, classification
Aвstract. Six polymorphic sequence-tagged microsatellite sites (STMSs) were used to characterize 65 accessions of old garden roses [OGRs (Rosa L. spp.)] from seven botanical sections and 13 horticultural groups. Aims of the study were to define the genetic profiles of accessions and to provide information useful for the classification and pedigree reconstruction of OGRs. In roses, a precise botanical classification is difficult due to repeated hybridization carried out in breeding; OGRs are classified in horticultural groups on the basis of their original parentage or of their morphological traits. A total of 82 alleles were detected at six loci. The number of alleles per locus ranged from six to 21, with an average of 13.7 alleles per locus. A dendrogram was constructed by cluster analysis, displaying the relative genetic similarities between species' accessions, hybrids, and cultivars. Cluster analysis grouped the genotypes into seven major clusters that were substantially consistent with their classification into botanical sections and horticultural groups. Several hypotheses of apportionment of accessions to horticultural groups were evaluated on the basis of the relative position in the dendrogram of the analyzed individuals. Results demonstrated that DNA analyses can contribute to drawing the botanic classification of rose accessions, improving the genetic knowledge on the background of modern rose, and providing the basis for breeding programs.
\end{abstract}

The genus Rosa contains over 150 species widely distributed throughout the northern hemisphere. It was divided into four subgenera: Hulthemia (Dumort.) Focke, Platyrhodon (Hurst) Rheder, Hesperhodos Cockerell, and Rosa Focke. The first three have been involved very little in the heritage of today's garden roses. Rosa, on the other hand, which accounts for almost all of the cultivated species of roses, grouped into 10 botanical sections [Banksianae Lindl., Bracteatae Thory, Caninae (DC.) Ser., Carolinae Crép., Indicae Thory, Cinnamomeae (DC.) Ser., Rosa (DC.) Ser., Laevigatae Thory, Pimpinellifoliae (DC.) Ser., and Synstylae DC.; Rehder, 1940], has given a substantial contribution to the genealogy of the modern rose. In particular, only seven to 10 species, mainly belonging to the sections Indicae, Rosa, Pimpinellifoliae, and Synstylae, were used to create the modern rose (Maia and Vénard, 1976).

The existence of numerous species and the large area of geographical distribution, together with the high level of interspecific and intersectional hybridization favored by the long breeding history, makes genetic relationships within the genus confusing. In most cases, the thousands of existing cultivars have a complex hybrid origin.

From a cytological point of view, the genus is characterized by a polyploid chromosomal series based on multiples of seven (Hurst, 1925). The chromosome numbers found in nature are $2 \mathrm{n}$ $=2 \mathrm{x}, 4 \mathrm{x}, 5 \mathrm{x}, 6 \mathrm{x}, 8 \mathrm{x}=14,21,28,35,42$, and 56 (Hurst, 1925, 1927): in the sections Banksianae, Bracteatae, Indicae, Laevigatae, and Synstylae 2n = 2x; in the Gallicanae 2n = 4x; in the Carolinae and Pimpinellifoliae $2 \mathrm{n}=2 \mathrm{x}$ and $4 \mathrm{x}$; in the Caninae

Received for publication 7 June 2005. Accepted for publication 5 Aug. 2005. We wish to thank Plant Research International (Wageningen, The Netherlands) for providing unpublished microsatellite loci primer sequences, Ben Vosman for the critical review of the manuscript, and Elena Costa for the help in morphological identification of rose accessions. We very much appreciated the enthusiastic support and helpful suggestions of Elena Accati.

1Dipartimento di Agronomia, Selvicoltura e Gestione del Territorio. To whom reprint requests should be addressed. E-mail address: valentina.scariot@unito.it 2Dipartimento di Colture Arboree.
$2 \mathrm{n}=4 \mathrm{x}, 5 \mathrm{x}$, and $6 \mathrm{x}$; and in the Cinnamomeae $2 \mathrm{n}=2 \mathrm{x}, 4 \mathrm{x}, 6 \mathrm{x}$, and $8 x$ (Yokoya et al., 2000). The modern cultivars are mostly tetraploid (Maia and Vénard, 1976).

The roses obtained before the breeding of 'La France' in 1867, the first Hybrid Tea rose, are generally called old garden roses. Several horticultural classifications, based on morphological traits, exist (Beales, 1985; Beales et al., 1998; Cairns, 2000; Dickerson, 1992, 1999; Harkness, 1978; Macoboy, 1993; Wissemann, 2003). Differences can be observed in the classification of cultivars or even in the attribution of a group of cultivars to a section. In fact, there are almost as many horticultural classifications as there are authors (Gudin, 2000).

Molecular markers have been used in the characterization and evaluation of genetic diversity in rose cultivars (especially modern) and in wild species; the most used techniques studied restriction fragment length polymorphism (RFLP) (Ballard et al., 1995; Hubbard et al., 1992; Rajapakse et al., 1992), mini- and microsatellite probe polymorphism (Vainsten and Ben-Meir, 1994), random amplified polymorphic DNA (RAPD) (Debener et al., 1996; Matsumoto and Fukui, 1996; Torres, 1993) and amplified fragment length polymorphism (AFLP) (Leus et al., 2004; Zhang et al., 2001).

Molecular markers have also become a tool in phylogenetic analyses of the genus Rosa (Ben Meir and Vainstein, 1994; Iwata et al., 2000; Martin et al., 2001; Matsumoto et al., 1997, 1998, 2000; Millan et al., 1996; Takeuchi et al., 2000; Wen et al., 2004; Wissemann and Ritz, 2005; Wu et al., 2000, 2001) and in the construction of genetic linkage maps (Debener and Mattiesch, 1999; Rajapakse et al., 2001a, 2001b). Furthermore, molecular markers can give access to DNA fragments potentially linked to genes involved in the control of important genetic traits (Debener et al., 2001a, 2001b). In fact, new and more efficient breeding strategies are needed due to the increasing demand for new rose cultivars. Many wild roses have desirable traits, such as superior disease resistance, higher fragrance levels, and absence of prickles on stems and petioles. The breeders' challenge is to transfer these 
desirable traits from the wild species $(2 \mathrm{n}=14)$ to modern rose cultivars $(2 \mathrm{n}=28)$ (Rajapakse et al., 2001b). The introgression of genes from wild roses into the genetic background of modern roses could be carried out if the genetic determinants of the more interesting traits and their chromosomal location were known (Debener and Mattiesch, 1999).

Sequence-tagged microsatellite sites (STMSs) [or simple sequence repeats (SSRs) or microsatellites] are hypervariable single-locus markers that have previously been shown to be highly informative in cultivar identification (Becher et al., 2000; Botta et al., 1995; Smulders et al., 2003; Testolin et al., 2000). Recently, Esselink et al. (2003) have developed and characterized STMS markers from $R$. $\times$ hybrida $\mathrm{L}$. to identify cut rose and rootstock cultivars. In comparison to RFLP, RAPD, and AFLP techniques, STMS markers have the potential to provide a more effective method for DNA fingerprinting because of the high repeatability of their analysis, high degree of polymorphism, co-dominant inheritance, and for their abundance and uniform distribution in the genome. Uncertainty exists about their usefulness in phylogenetic studies. The main concerns in using microsatellites arise from their usually high mutation rates, which might lead to inconsistencies due to homoplasies, and from their limited range of allele sizes. However, previous studies revealed that microsatellites can be used for establishing genealogies. In Lycopersicon Mill., a SSRbased dendrogram matched a previous RFLP-based one and the biosystematic of the genus (Alvarez et al., 2001). In Oryza sativa L., Hashimoto et al. (2004) obtained two essentially equivalent trees using, independently, AFLP and microsatellite markers. In this paper we demonstrated that microsatellite markers are useful to describe the genetic diversity of roses and to establish genetic relationships among accessions. The understanding of relationships among cultivated species and cultivars is a prerequisite for the effective utilization of the genetic variability available to a breeder (Takeuchi et al., 2000). The usefulness of grouping all the known species and their hybrids into sections is evident, as the procedure simplifies the study of rose development. In this study, the species and the cultivars of OGRs were chosen to represent the main horticultural groups in order to clarify their genetic relationships and to compare the STMS genealogy thus obtained with morphological classifications and known pedigree information. Six microsatellite loci, located on at least four different linkage groups, were chosen. Their location over the genome allows one to avoid conclusions on genetic relatedness of rose accessions merely based on markers from one or a few chromosomal regions (Debener et al., 2001a). The sampled accessions differed in ploidy level and many of them were never DNA-typed.

\section{Material and methods}

Plant material. Eighteen species and forms and 47 hybrids and cultivars of roses grown in the Roseraie "Carla Fineschi" at Cavriglia (Arezzo, Italy) were selected for this study (Table 1); they included five of the 10 species that concurred most in the origin of the known cultivars. Hybrids and cultivars were chosen among the horticultural groups Alba (3), Bourbon (5), Centifolia (4), Hybrid China (3), Hybrid Rugosa (1), Damask (2), Gallica (8), Moss (3), Noisette (3), Hybrid Perpetual (3), Portland (7), Tea (4), and Hybrid Spinosissima (1). These groups belong to the sections Caninae, Carolinae, Indicae, Cinnamomeae, Rosa, Pimpinellifoliae, and Synstylae. Previous to DNA analysis, all plants were observed to confirm their identity by morphological traits and literature descriptions (Beales, 1985; Beales et al.,
Table 1. List of the wild rose species and of the old garden roses sampled in May 2002 at the Roseraie "Carla Fineschi" at Cavriglia (Arezzo, Italy). Accessions are sorted by horticultural group and alpha-numerical names.

\begin{tabular}{rlll}
\hline ID no. & Section & Group & \multicolumn{1}{c}{ Accession } \\
\hline 32 & Caninae & & $R$. canina L. \\
50 & Caninae & & $R$. horrida Bess. Ex \\
& & & Fisch. \\
5 & Caninae & & R. rubiginosa L. \\
39 & Caninae & Alba & 'Alba Semiplena' \\
17 & Caninae & Alba & 'Alba Suaveolens' \\
30 & Caninae & Alba & 'Cuisse de Nymphe' \\
28 & Caninae & & $R$. carolina L. \\
61 & Caninae & & $R$. palustris Marsh. \\
9 & Caninae & & $R$. virginiana Mill. \\
35 & Indicae & & $R$. ×odorata (Andrews) \\
& & & Sweet var. gigantea \\
& & & (Collett ex Crép.) Rehder \\
& & & \& E.H. Wilson \\
14 & Indicae & Hybrid China & 'Old Blush' \\
59 & Indicae & Hybrid China & 'Rivers' George IV' \\
42 & Indicae & Hybrid China & 'Viridiflora' \\
53 & Indicae & Noisette & 'Aimée Vibert' \\
21 & Indicae & Noisette & 'Blush Noisette' \\
48 & Indicae & Noisette & 'Champneys' Pink Cluster' \\
18 & Indicae & Tea & 'Parks' Yellow Tea-Scent-
\end{tabular}

18 Indicae

Tea

ed

$\begin{array}{rll}62 & \text { Indicae } & \text { Tea } \\ 23 & \text { Indicae } & \text { Tea } \\ 70 & \text { Indicae } & \text { Tea } \\ 7 & \text { Cinnamomeae } & \\ 13 & \text { Cinnamomeae } & \end{array}$

Cinnamomeae

Hybrid Rugosa

Rosa

Bourbon

Rosa

Rosa

Bourbon

24 Rosa

Bourbon

Bourbon

67 Rosa

Bourbon

36

Rosa

\section{Centifolia}

Centifolia

Centifolia

Centifolia

Damask

Damask

Gallica

Gallica

Gallica

Gallica

Gallica

Gallica

'Parks' Yellow Tea-Scent-

\section{China'}

'President'

'Safrano'

'Triomphe du Luxembourg'

R. majalis Herrm.

R. macrophylla Lindl.

'Rubricaulis'

R. rugosa Thunb. 'Rubra'

$R$. ×borboniana N.H.F.

Desp.

'Hermosa'

'Louise Odier'

'Paul Ricault'z

'Souvenir de la

Malmaison'

R. ×centifolia L. 'Rubra'

'Petite de Hollande'

'Petite Lisette'z

'Unique Blanche'

'Kazanlik'

'York and Lancaster'

'Alain Blanchard'

'Belle de Crécy'z

'Cardinal de Richelieu'z

'Duchesse de Montebello'z

'Jenny Duval'z

R. gallica L. 'Conditorum' Dieck

$38 \quad$ Rosa Gallica

R. gallica 'Officinalis' Thory

Gallica 'The Bishop'z

Hybrid Perpetual 'Baronne Prévost'

Hybrid Perpetual 'Exposition de Brie'z

Table 1 continued on next page. 
Table 1. Continued from previous page.

\begin{tabular}{|c|c|c|c|}
\hline ID no. & Section & Group & Accession \\
\hline 51 & Rosa & Moss & 'Crested Moss' \\
\hline 37 & Rosa & Moss & 'Mousseux du Japon' \\
\hline 41 & Rosa & Moss & $\begin{array}{l}\text { 'Quatre Saisons Blanc } \\
\text { Mousseux'z }\end{array}$ \\
\hline 68 & Rosa & Portland & 'Blanc de Vibert' \\
\hline 26 & Rosa & Portland & 'Coelina Dubos'z \\
\hline 31 & Rosa & Portland & 'Duchess of Portland' \\
\hline 64 & Rosa & Portland & $\begin{array}{l}\text { 'La Quatre Saisons } \\
\text { Continue' }\end{array}$ \\
\hline 12 & Rosa & Portland & 'Rose de Puteaux' \\
\hline 65 & Rosa & Portland & 'Rose du Roi' \\
\hline 54 & Rosa & Portland & 'Yolande d'Aragone' \\
\hline 57 & Pimpinellifoliae & & $\begin{array}{l}\text { R. elegantula Rolfe } \\
\text { 'Persetosa' Stapf }{ }^{\mathrm{z}}\end{array}$ \\
\hline 16 & Pimpinellifoliae & & R. foetida Herrm. \\
\hline 19 & Pimpinellifoliae & & R. sericea Lindl. \\
\hline 10 & Pimpinellifoliae & & R. spinosissima $\mathrm{L}$. \\
\hline 44 & Pimpinellifoliae & & $\begin{array}{l}\text { R. xanthina Lindl. f. } \\
\text { hugonis (Hemsl.) }\end{array}$ \\
\hline 66 & Pimpinellifoliae & $\begin{array}{l}\text { Hybrid } \\
\text { Spinosissima }\end{array}$ & 'Andrewsii'z \\
\hline 8 & Synstylae & & R. moschata Herrm. \\
\hline 4 & Synstylae & & R. multiflora Thunb. \\
\hline 15 & Synstylae & & R. sempervirens L. \\
\hline 63 & & & R. aschersoniana Crép. \\
\hline
\end{tabular}

${ }^{2}$ Accessions of uncertain classification are sorted according to the results of the present study.

1998; Cairns, 2000; Dickerson, 1992, 1999; Harkness, 1978; Macoboy, 1993). Some accessions have discordant horticultural classifications, depending on the author.

DNA EXTRACTION. Leaves were harvested in spring, deepfrozen to $-70{ }^{\circ} \mathrm{C}$ for storage and then reduced to a fine powder in liquid nitrogen using a mortar and pestle. DNA was extracted from about $0.12 \mathrm{~g}$ of tissue in a $2 \%$ CTAB buffer (CTAB 2\%, 1.4 $\mathrm{M} \mathrm{NaCl}, 20$ mм EDTA pH 8.0, 100 mм Tris-HCl pH 8.0, 1\% PVP $40.000,2 \% \beta$-mercaptoethanol), following the protocol by Doyle and Doyle (1990) with minor modifications. The extracted DNA was resuspended after purification in $70 \mu \mathrm{L}$ Tris-EDTA buffer. The DNA was quantified by spectrophotometry.

STMS AMPLIFICATION. STMSs were amplified by PCR in a $20 \mu \mathrm{L}$ reaction volume containing $2 \mu \mathrm{L} 10 \mathrm{X}$ PCR buffer $(100$ mm Tris- $\mathrm{HCl}, \mathrm{pH} 8.3,500 \mathrm{~mm} \mathrm{KCl}$ ), $1.5 \mathrm{~mm} \mathrm{MgCl}_{2}, 0.5 \mu \mathrm{M}$ of each primer, $200 \mu \mathrm{m}$ dNTP, $0.5 \mathrm{U}$ Taq-DNA polymerase (AmpliTaq Gold DNA polymerase; Applied Biosystems, Foster City, Calif.), and $50 \mathrm{ng}$ template DNA. The amplifications were performed in a thermal cycler (PTC 100; MJ Research, Watertown, Mass.).

The primers used were RhAB22, RhE2b, RhD221, RhO517, RhEO506, and RhP519 developed by Esselink et al. (2003). The forward primers were labeled with a fluorochrome (6-FAM, HEX, or NED).

Amplification cycles consisted of an initial step of 11 min at 95 ${ }^{\circ} \mathrm{C}$, followed by 26 cycles of $30 \mathrm{~s}$ at $95^{\circ} \mathrm{C}, 40 \mathrm{~s}$ at $55^{\circ} \mathrm{C}, 1 \mathrm{~min}$ $30 \mathrm{~s}$ at $72^{\circ} \mathrm{C}$, with a final extension step of $45 \mathrm{~min}$ at $72{ }^{\circ} \mathrm{C}$.

DETECTION OF STMS POLYMORPHISM. One microliter of a mix containing amplification products of three different labeled loci was added to $3 \mu \mathrm{L}$ of a mix containing 10:2:1 parts of formamide, GeneScan-350 ROX size standard (Applied Biosystems) and load- ing buffer ( $25 \mathrm{~mm}$ EDTA, $50 \mathrm{mg} \cdot \mathrm{mL}^{-1}$ blue dextran). Fluorescent samples were denatured at $95^{\circ} \mathrm{C}$ for $5 \mathrm{~min}$ and DNA fragments were separated on a sequencing gel $(4.25 \%$ acrylamide, $1 \mathrm{X}$ TBE buffer, 6 м urea) using an ABI-PRISM 377 DNA sequencer with GeneScan software (Applied Biosystems).

Data analysis. According to previous studies (Becher et al., 2000; Esselink et al., 2003; Rajapakse et al., 2001a), gels were scored in a binary format. Banding patterns observed at a particular locus were therefore recorded as a presence/absence matrix and are referred to as "allelic phenotypes" (Becher et al., 2000). The number of alleles per locus and the number of allelic phenotypes were calculated for all the genotypes together and for each section.

The binary data were used to compute pair-wise similarity coefficients (Jaccard, 1908) using SPSS (version 11.01; SPSS, Inc., Chicago). The obtained similarity matrix was subjected to cluster analysis by the unweighted pair-group method of arithmetic averages method (UPGMA). Bootstrapping was applied to evaluate the reproducibility of the ordination in a statistical way using PHYLIP version 3.5c (Felsenstein, 1993). The amount of replacement was fixed to $2 \%$ of the markers per bootstrap. Multiple data sets were generated by 100 resampling cycles.

\section{Results}

DATA SCORING AND CHARACTERIZATION. Eighteen species and forms and 47 hybrids and cultivars of OGRs, representing various taxonomic sections and horticultural groups, were analyzed in duplicate with six microsatellite markers. The presence/absence of the alleles was established using a threshold value for allele assignment, according to Esselink et al. (2003).

In order to quantify the discriminating power of the loci, the number of allelic phenotypes was counted (Esselink et al., 2003) both for all the genotypes considered together (Table 2) and for the genotypes subdivided into the botanical sections (Tables 3-4). Sixty-one allelic phenotypes were found in 65 accessions. The six markers attributed unique allelic phenotypes and identified all the wild species while identical phenotypes were found within OGR cultivars for $R$. × centifolia L. 'Rubra' and 'Crested Moss' for 'Kazanlik', 'Quatre Saisons Blanc Mousseux', and 'York and Lancaster', and for 'Old Blush' and 'Viridiflora'. Unique alleles were observed, especially in species.

A total of 82 alleles were detected at six loci. The number of alleles per locus ranged from six to 21 , with an average of 13.7 alleles per locus. The number of allelic phenotypes per locus ranged from 14 to 50 with an average of 34.7. Different discriminating

Table 2. Characteristics of the six microsatellite loci studied in 65 rose accessions.

\begin{tabular}{lccc}
\hline $\begin{array}{l}\text { STMS } \\
\text { marker }\end{array}$ & $\begin{array}{c}\text { Linkage } \\
\text { group }\end{array}$ & $\begin{array}{c}\text { Alleles } \\
\text { (no.) }\end{array}$ & $\begin{array}{c}\text { Allelic } \\
\text { phenotypes } \\
(\text { no. })^{\mathrm{x}}\end{array}$ \\
\hline RhAB22 & 6 & 19 & 44 \\
RhE2b & Not determined & 15 & 45 \\
RhD221 & 4 & 11 & 26 \\
RhEO506 & 2 & 21 & 50 \\
RhP519 & Not determined & 10 & 28 \\
RhO517 & 1 & 6 & 15
\end{tabular}

${ }^{2}$ Sequence-tagged microsatellite site markers developed and characterized by Esselink et al., 2003.

yDebener et al., 2001a.

${ }^{x}$ As defined by Becher et al., 2000. 
Table 3. Number of different alleles in the examined rose sections obtained studying the six microsatellite loci. Rosa aschersoniana and $R$. elegantula 'Persetosa' are not included in this table because of their uncertain attribution to a section.

\begin{tabular}{lccccccc}
\hline & \multicolumn{5}{c}{ Different alleles (no.) } \\
\cline { 2 - 7 } STMS marker & Caninae & Carolinae & Indicae & Cinnamomeae & Rosa & Pimpinellifoliae & Synstylae \\
\hline RhAB22 & 5 & 5 & 8 & 7 & 8 & 5 & 5 \\
RhE2b & 8 & 1 & 7 & 5 & 8 & 4 & 5 \\
RhD221 & 7 & 2 & 4 & 3 & 7 & 5 & 4 \\
RhEO506 & 10 & 4 & 12 & 6 & 14 & 7 & 5 \\
RhP519 & 8 & 3 & 6 & 6 & 6 & 4 & 4 \\
RhO517 & 2 & 2 & 6 & 2 & 5 & 4 & 3 \\
\hline
\end{tabular}

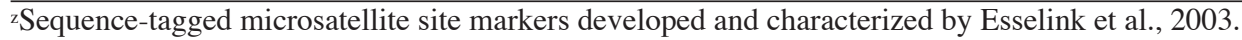

Table 4. Number of different allelic phenotypes obtained at six loci in the examined sections. Rosa aschersoniana and $R$. elegantula 'Persetosa' are not included in this table because of their uncertain attribution to a section.

\begin{tabular}{|c|c|c|c|c|c|c|c|}
\hline \multirow[b]{2}{*}{ STMS marker $^{\mathrm{y}}$} & \multicolumn{7}{|c|}{ Allelic phenotypes (no.) $)^{\mathrm{z}} /$ Accessions (no.) } \\
\hline & Caninae & Carolinae & Indicae & Cinnamomeae & Rosa & Pimpinellifoliae & Synstylae \\
\hline RhAB22 & $5 / 6$ & $3 / 3$ & $8 / 11$ & $3 / 3$ & $17 / 32$ & $5 / 5$ & $3 / 3$ \\
\hline RhE2b & $5 / 6$ & $1 / 3$ & $8 / 11$ & $3 / 3$ & $22 / 32$ & $4 / 5$ & $3 / 3$ \\
\hline RhD221 & $6 / 6$ & $2 / 3$ & $5 / 11$ & $2 / 3$ & $12 / 32$ & $3 / 5$ & $3 / 3$ \\
\hline RhEO506 & $5 / 6$ & $3 / 3$ & $10 / 11$ & $3 / 3$ & $20 / 32$ & $5 / 5$ & $3 / 3$ \\
\hline RhP519 & $6 / 6$ & $3 / 3$ & $7 / 11$ & $3 / 3$ & $10 / 32$ & $5 / 5$ & $3 / 3$ \\
\hline RhO517 & $1 / 6$ & $2 / 3$ & $6 / 11$ & $2 / 3$ & $7 / 32$ & $5 / 5$ & $3 / 3$ \\
\hline
\end{tabular}

${ }^{\mathrm{z} A s}$ defined by Becher et al., 2000.

ySequence-tagged microsatellite site markers developed and characterized by Esselink et al., 2003.

abilities for each locus were observed considering separately the diverse sections. Loci RhD221 and RhP519 yielded six allelic phenotypes, one for each of the six accessions of the section Caninae. Loci RhAB22, RhEO506, and RhP519 produced three allelic phenotypes for the three genotypes of the section Carolinae, while locus RhEO506 separated the 11 accessions of the section Indicae into 10 allelic phenotypes.

For the section Cinnamomeae, all loci but RhD221 and $\mathrm{RhO} 517$ discriminated the three analyzed genotypes. The most discriminating locus for the section Rosa was RhE2b with 22 allelic phenotypes for 32 genotypes. In the section Pimpinellifoliae, all loci but RhE2b and RhD221 were able to identify the five accessions, while in the section Synstylae all loci were able to distinguish the three accessions.

Cluster analysis of the STMS amplification data. Seven major clusters (A, BC, D, E, F, G, H) could be distinguished that are all supported by high bootstrap values $(>70 \%)$ but clusters $A$ and $G$ (Fig. 1). Cluster A and subcluster B contained almost all the accessions of the section Rosa (native to northern Europe, Mongolia, and China). Cluster A included all horticultural groups but Hybrid Perpetual and Bourbon roses, that are found in subcluster B.

Subcluster $\mathrm{C}$ and clusters $\mathrm{E}$ and $\mathrm{F}$ comprised the accessions of the section Indicae (native to Southeast Asia); cluster E included Tea roses and the cultivar Souvenir de la Malmaison.

Cluster D grouped all Caninae roses (European and Middle Eastern origin) and formed two subbranches, one for the cultivars (group Alba) and the second for the species. Cluster G contained the sections Pimpinellifoliae (native to Europe, Mongolia, and China), Carolinae (southeastern U.S. origin) and Cinnamomeae (spread across northern North America, eastern Europe, and most of China). A small cluster $(\mathrm{H})$ was set apart and was constituted by only two accessions: $R$. moschata Herrm., belonging to the section Synstylae (broad, diverse range of distribution across Europe, Southeast Asia, and northeastern North America) and $R$. xodorata (Andrews) var. gigantea (Collet ex Crép.) Rehder
$\&$ E.H. Wilson, belonging to the section Indicae. The other two species (R. multiflora Thunb. and R. sempervirens L.) of the section Synstylae considered in this work were located in clusters $A$ and $F$, respectively.

Horticultural groups Centifolia, Alba, Hybrid China, and Tea formed distinct clusters in the dendrogram, supported by high bootstrap values.

\section{Discussion}

DATA SCORING AND CHARACTERIZATION. STMS markers are highly polymorphic and informative. Some of the STMS primers developed in one species may be effective in detecting polymorphism in other related species. We tested six STMS primer pairs developed in $R$. $\times$ hybrida. All primer pairs were successful in amplifying alleles at these six STMSs. In particular, all STMS primers amplified polymorphic alleles in 18 different rose species. This may indicate that these microsatellite loci are conserved within the genus Rosa, but it may also mean that genomes of the species are highly homologous (Esselink et al., 2003).

The co-dominant nature of STMS markers allows determination of the actual genotype of an individual and estimation of allelic relationships among the genotypes. However, co-dominant scoring of the markers in heterozygote samples is complicated in polyploid individuals (Creste et al., 2003; Esselink et al., 2003). In this study, differences were detected in the amount of amplification product for different alleles of a particular genotype. However, it seems very difficult to use these differences in a reliable way to estimate whether a particular allele was present in one or more copies, and thus to deduce the effective genotype of an individual. Therefore, the scoring was done in a dominant way (the presence/absence of alleles was scored and recorded as a binary matrix) and consequently the band pattern observed did not allow the definition of the allelic genotype of the individual. For this reason the DNA profile of each accession was defined as "allelic phenotype," according to Becher et al. (2000). 


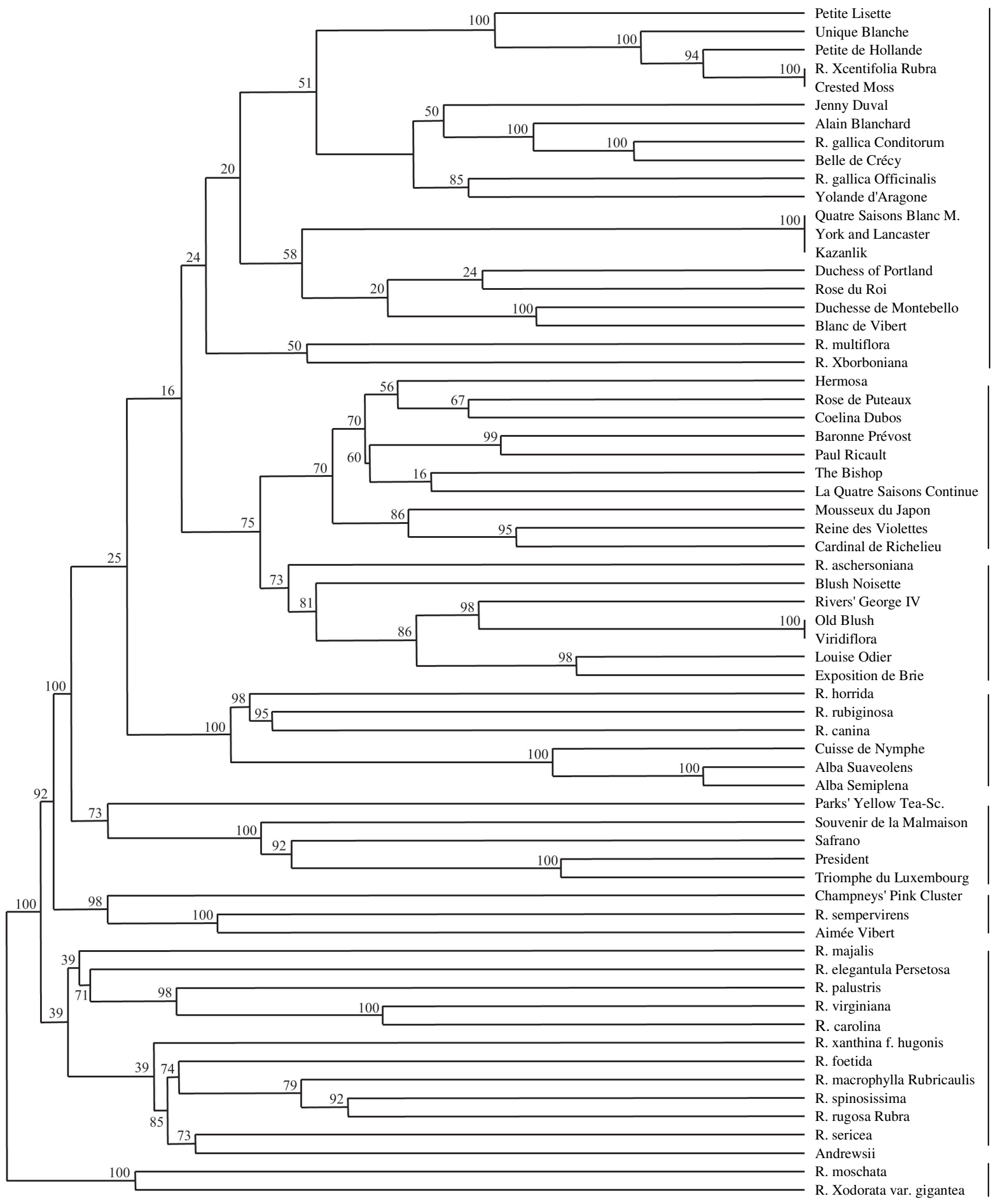

A

B

C

D

E

F

G

Fig. 1. Dendrogram depicting the genetic relationships among 65 Rosa accessions (Jaccard similarity coefficient; UPGMA clustering) with indication of boostrap values of 100 datasets. 
The microsatellite DNA allele counting-peak ratio (MAC-PR) method was recently developed in the analysis of polyploid plants using the quantitative values of microsatellite allele peak areas for distinguishing single-copy by multiple-copy alleles.

This method was applied on a set of tetraploid ornamental rose (R. $\times$ hybrida) cultivars (Esselink et al., 2004). It will be interesting to test the method on a larger number of cultivars from different species to improve its accuracy and allow the processing of data using diversity indexes based on allele frequencies.

Phylogenetic analysis. Central to the issue of whether microsatellites are good phylogenetic markers is the consideration of their mode and rate of evolution (Fisher et al., 2000). Empirical studies on crab (Limulus polyphemus L.) (Ortì et al., 1997), bear (Ursus L.) (Paetkau et al., 1997), and soybean (Glycine Willd.) (Doyle et al., 1998) showed the existence of serious problems in using microsatellites to reconstruct known species relationships because of the size homoplasy and the constraints on allele distributions. On the other hand, studies on Drosophila melanogaster Meigen species complex were more successful. Microsatellite phylogenies accurately mirrored the differentiation both in gray fox (Urocyon cinereoargenteus Schreber) and Coccidioides immitis Stiles populations (Fisher et al., 2000). According to Nauta and Weissing (1996), genetic distance measures applied to microsatellite data can yield useful estimators for phylogenetic relationships in a short-term perspective and in small populations. For Takezaki and Nei (1996), microsatellites are very useful at least for studying closely related populations.

These conclusions were achieved as well when not wild populations but species accessions and cultivars were analyzed. Dendrograms based on microsatellite polymorphisms showed reliable topology both in Lycopersicon species (Alvarez et al., 2001) and Oryza sativa cultivars (Hashimoto et al., 2004).

In this study the UPGMA clustering of Jaccard similarities was in good agreement with the botanical classification and the horticultural literature. In fact, genotypes were grouped into seven major clusters that were substantially consistent with their classification into botanical sections and horticultural groups. Two clusters (A and $G$ ) were not supported by high bootstrap values and therefore they should be regarded with caution. Yet values of nodes coming behind or preceding $(\mathrm{G})$ are higher, and thus the structure of the dendrogram is not expected to substantially change as concerns the grouping of accessions but rather on the relative position of major clusters. Furthermore, the dendrogram showed several correspondences with phylogenetic approaches based on the matK sequence (Matsumoto et al., 1998) and on the restriction enzyme analysis of the chloroplast DNA (Takeuchi et al., 2000). All this implies that microsatellites can be used for establishing relationships between related species and cultivars, taking into account that their level of variability may improve their effectiveness (Alvarez et al., 2001).

In this research, phylogenetic analysis was helpful to clarify questions about the origin and classification of many OGRs whose position is still uncertain.

Cultivar SPORTS. In rose, mutants or "sports" are frequently observed. Most easily detectable are mutations in the color of the flower. As sports usually are the result of just very few changes in the genetic makeup of a cultivar, the genetic similarity between original cultivar and sport is very high. According to Vosman et al. (2004), a safe separation line between essentially derived varieties (EDV) obtained by mutation and non-EDV can be set at a Jaccard genetic similarity of 0.95 .

Observing the accessions clustering at distance zero in the dendrogram, some hypotheses about the origin of cultivars sharing the same allelic profile were raised or confirmed. 'Crested Moss', apportioned to the Centifolias (Cairns, 2000) or to the Moss (Beales et al., 1998), is considered by some authors as a seedling of $R$. ×centifolia (Beales et al., 1998). According to these data, 'Crested Moss' shared the same allelic profile with $R$. ×centifolia 'Rubra'. That it originates from this hybrid accession is thus confirmed but 'Crested Moss' is more likely a sport of the accession 'Rubra' than a seedling. 'Quatre Saison Blanc Mousseaux', 'Kazanlik', and 'York and Lancaster' are clustered as a single allelic phenotype, in agreement with Iwata et al. (2000). The first cultivar is a known sport of 'Quatre Saison' (selected by M. Laffay prior to 1837) and belongs to the Moss group (Beales et al., 1998; Cairns, 2000; Harkness, 1978); 'Kazanlik' and 'York and Lancaster' are two accessions of unknown origin morphologically similar to 'Quatre Saison' with deep pink and pink blended flowers, respectively. Lastly, data confirmed the possibility that 'Viridiflora' is a sport of 'Old Blush' (Beales et al., 1998).

Results did not confirm the hypotheses about the origin or identity of 'Coelina Dubos' and 'Alba Suaveolens'. 'Coelina Dubos' is believed to be a sport of 'Rose de Roi' (Dickerson, 1992), and clustered in a different branch of the dendrogram; 'Alba Suaveolens', considered by Beales (1985) synonymous with 'Alba Semiplena', showed a different genetic profile.

Apportionment to groups and Sections. The closeness between sections Carolinae and Cinnamomeae, which are sometimes merged together because of morphological similarity (Matsumoto et al., 1998), was confirmed by our analysis. Two cases of uncertain attribution to these sections were examined: 'Andrewsii', considered belonging either to the section Pimpinellifoliae (Beales, 1985) or to the section Rosa, Moss group (Beales et al., 1998), was genetically closer to Pimpinellifoliae; R. elegantula Rolfe 'Persetosa' Stepf., apportioned to the section Pimpinellifoliae (Cairns, 2000) or Cinnamomeae (Beales, 1985), was located in cluster G, which included Pimpinellifoliae, Cinnamomeae, and Carolinae but could not be assigned for sure to any of the three sections.

Several questions concern the proper apportionment of cultivars either to Rosa or to Indicae. In more detail, 'Cardinal de Richelieu' and 'Hermosa', whose proper apportionment to Hybrid China or Gallica ('Cardinal de Richelieu') and to Hybrid China or Bourbon ('Hermosa') is uncertain, clustered in the Rosa section and thus may indeed belong to the Gallica and Bourbon groups, respectively. 'Jenny Duval' and 'Belle de Crécy', classified either within the Gallica or within the Hybrid China roses (Beales, 1985; Beales et al., 1998; Cairns, 2000; Dickerson, 1999), are found in the same branch together with the two Gallica accessions $R$. gallica L. 'Conditorum' Diek and R. gallica 'Officinalis' Thory. 'Souvenir de la Malmaison', obtained by a cross between a Bourbon ('Mme Desprez') and a Tea cultivar (pollinizer) and considered a Bourbon rose (Beales et al., 1998; Harkness, 1978), was located within the Tea group in this study. Finally, 'Duchesse de Montebello', either apportioned to the Gallica (Beales, 1985; Beales et al., 1998; Cairns, 2000) or to the Noisette (Dickerson, 1999) roses, resulted being grouped in the section Rosa.

Several questions concern the proper apportionment of cultivars within the Rosa section. 'Petite Lisette', apportioned by authors to different cultural groups (Alba, Agathe, Centifolia, Damask, and Gallica) (Dickerson, 1999), clustered with the Centifolias. 'Alain Blanchard', which is considered a cross of $R$. $\times$ centifolia $\times$ R. gallica (Beales et al., 1998; Cairns, 2000) and 
thus either apportioned to the Centifolias (Dickerson, 1999) or to the Gallicas (Beales, 1985; Beales et al., 1998; Cairns, 2000), and 'Yolande d'Aragone', a Portland rose, were located in the same branch with the Gallicas. The other Portland roses are found rather spread in clusters $\mathrm{A}$ and $\mathrm{B}$, as expected due to their broad genetic basis (Gallicas, Damasks, Centifolias, and Hybrid Chinas). 'Paul Ricault', apportioned to the Centifolias (Beales et al., 1998; Cairns, 2000) or to the Bourbons (Dickerson, 1992), did not cluster with Centifolia accessions. Still unsolved (Gallica or Centifolia?) remains the case of cultivar The Bishop (Beales et al., 1998; Cairns, 2000; Dickerson, 1999).

Finally, 'Exposition de Brie', classified as a Floribunda (a group of modern roses) (Cairns, 2000) or a Hybrid Perpetual (Beales et al., 1998; Dickerson, 1992), is clustered with a Bourbon ('Louise Odier'), the group from which the Hybrid Perpetuals derive.

\section{Conclusions}

In this paper, phylogenetic analysis using STMS markers was carried out to help clarify the classification of OGRs.

Studies of phylogenetic relationships among very closely related species can be hampered by a lack of variation. In this study, the six microsatellite primer sets analyzed amplified polymorphic loci across the genus Rosa. The good cross-species transferability that was observed thus makes this set of microsatellite loci an appropriate tool for rose germplasm management. Yet the use of microsatellite DNA for studying the evolutionary relationships is debated. Our results suggest that microsatellites are useful markers for establishing relationships between species and cultivars. In roses, repeated hybridization has made precise botanical classification difficult. OGRs are classified in horticultural groups on the basis of their original parentage (which is often hypothesized for ancient cultivars) or by their morphological traits. Accessions belonging to a group could be redetermined following advances of the research. For example, Moss roses are believed to be derived from natural mutation of the Centifolias and according to Harkness (1978) they should be included in this last group. However, moss sports can rise in other groups (Damasks and Hybrid of $R$. spinosissima L.) as the present results demonstrated ('Quatre Saisons Blanc Mousseux' and 'Andrewsii').

DNA analyses can contribute to clarifying the classification defining the closeness and the distances between cultivars and horticultural groups. Anew classification could thus be drawn once further data are acquired and be the basis for breeding programs. Yet it will depict genetic relationships rather than separate accessions into horticultural groups. A botanic classification based on DNA data will be useful to improve the genetic knowledge on the background of modern roses, while a classification laying on traits of agronomic relevance could be maintained for horticultural purposes.

\section{Literature Cited}

Alvarez, A.E., C.C.M. van de Wiel, M.J.M. Smulders, and B. Vosman. 2001. Use of microsatellites to evaluate genetic diversity and species relationships in the genus Lycopersicon. Theor. Appl. Genet. 103:1283-1292.

Ballard, R., S. Rajapakse, A. Abbott, and D. Byrne. 1995. DNA markers in rose and their use for cultivar identification and genome mapping. Acta Hort. 424:265-268.

Beales, P. 1985. Classic roses. Collins Harvill, London.

Beales, P., T. Cairns, W. Duncan, G. Fagan, W. Grant, K. Grapes, P. Harkness, K. Hughes, J. Mattock, and D. Ruston. 1998. Botanica's roses. The encyclopedia of roses. Grange Books, Kent, U.K.

Becher, S.A., K. Steinmetz, K. Weising, S. Boury, D. Peltier, J-P. Renou, G. Kahl, and K. Wolff. 2000. Microsatellites for cultivar identification in Pelargonium. Theor. Appl. Genet. 101:643-651.

Ben-Meir, H. and A. Vainstein. 1994. Assessment of genetic relatedness in roses by DNA fingerprint analysis. Scientia Hort. 58:115-121.

Botta, R., N.S. Scott, I. Eynard, and M.R. Thomas M R. 1995. Evaluation of microsatellite sequence-tagged site markers for characterizing Vitis vinifera cultivars. Vitis 34(2):99-102.

Cairns, T. 2000. Modern roses XI. The world encyclopedia of roses. Amer. Rose Soc. Academic Press, San Diego.

Creste, S., A. Tulmann Neto, S. de Oliveira Silva, and A. Figueira. 2003. Genetic characterization of banana cultivars (Musa spp.) from Brazil using microsatellite markers. Euphytica 132:259-268.

Debener, T., C. Bartels, and L. Mattiesch. 1996. RAPD analysis of genetic variation between a group of rose cultivars and selected wild rose species. Mol. Breeding 2:321-327.

Debener, T. and L. Mattiesch. 1999. Construction of a genetic linkage map for roses using RAPD and AFLP markers. Theor. Appl. Genet. 99:891-899.

Debener, T., L. Mattiesch, and B. Vosman. 2001a. A molecular marker map for roses. Acta Hort. 547:283-287.

Debener, T., B. Von Malek, L. Mattiesch, and H. Kaufmann. 2001b. Genetic and molecular analysis of important characters in roses. Acta Hort. 547:45-49.

Dickerson, B.C. 1992. The old rose advisor. Timber Press, Portland, Ore.

Dickerson, B.C. 1999. The old rose adventurer. The once-blooming old European roses and more. Timber Press, Portland, Ore.

Doyle, J.J. and L. Doyle. 1990. Isolation of plant DNA from fresh tissue. Focus 12:13-15.

Doyle, J.J., M. Morgante, S.V. Tingey, and W. Powell. 1998. Size homoplasy in chloroplast microsatellites of wild perennial relatives of soybean (Glycine subgenus Glycine). Mol. Biol. Ecol. 15(2):215-218.

Esselink, G.D., H. Nybom, and B. Vosman. 2004. Assignment of allelic configuration in polyploids using the MAC-PR (microsatellite DNA allele counting-peak ratios) method. Theor. Appl. Genet. 109:402-408.

Esselink, G.D., M.J.M. Smulders, and B. Vosman. 2003. Identification of cut rose (Rosa hybrida) and rootstock varieties using robust sequence tagged microsatellite site markers. Theor. Appl. Genet. 106:277-286.

Felsenstein, J. 1993. PHYLIP (Phylogeny Inference Package) version 3.5c. Dept. of Genetics, Univ. of Washington, Seattle.

Fisher, M.C., G. Koenig, T.J. White, and J.W. Taylor. 2000. A test for concordance between the multilocus genealogies of genes and microsatellites in the pathogenic fungus Coccidioides immitis. Mol. Biol. Evol. 17(8):1164-1174.

Gudin, S. 2000. Rose: Genetics and breeding. Plant Breeding Rev. 17:159-189.

Harkness, J. 1978. Roses. Dent, London.

Hashimoto, Z., N. Mori, M. Kawamura, T. Ishii, S. Yoshida, M. Ikegami, S. Takumi, and C. Nakamura. 2004. Genetic diversity and phylogeny of Japanese sake-brewing rice as revealed by AFLP and nuclear and chloroplast SSR markers. Theor. Appl. Genet. 109:1586-1596.

Hubbard, M., J. Kell, S. Rajapakse, A. Abbott, and R. Ballard. 1992. Restriction fragment length polymorphism in rose and their use for cultivar identification. HortScience 27:172-173.

Hurst, C.C. 1925. Chromosomes and characters in Rosa and their significance in the origin of species. Expt. Genet. 37:534-550.

Hurst, C.C. 1927. Differential polyploidy in the genus Rosa L. Verhandlungen des V Internationalen Kongresses fur Vererbungswissenschaft, Suppl. 2(1928):867-906.

Iwata, H., T. Kato, and S. Ohno. 2000. Triparental origin of Damask roses. Gene 259:53-59.

Jaccard, P. 1908. Nouvelles recherches sur la distribution florale. Bul. Soc. Vaudoise Sci. Nat. 44:223-270. 
Leus, L., F. Jeanneteau, J. Van Huylenbroeck, E. Van Bockstaele, and J De Riek. 2004. Molecular evaluation of a collection of rose species and cultivars by AFLP, ITS, $r b c \mathrm{~L}$ and matK. Acta Hort. 651:141-147.

Macoboy, S. 1993. The ultimate rose book. Abrams, New York.

Maia, N. and P. Vénard. 1976. Cytotaxonomie du genre Rosa et origine des rosiers cultivés, p. 7-20. In: Travaux sur rosier de serre, INRA Editions, Paris.

Martin, M., F. Piola, D. Chessel, M. Jay, and P. Heizmann. 2001. The domestication process of the modern rose: Genetic structure and allelic composition of the rose complex. Theor. Appl. Genet. 102:398-404.

Matsumoto, S. and H. Fukui. 1996. Identification of rose cultivars and clonal plants by random amplified polymorphic DNA. Scientia Hort. 67:49-54.

Matsumoto, S., H. Wakita, and H. Fukui. 1997. Molecular classification of wild roses using organelle DNA probes. Scientia Hort. 68:191-196.

Matsumoto, S., M. Kouchi, J. Yabuki, M. Kusunoki, Y. Ueda, and H. Fukui. 1998. Phylogenetic analyses of the genus Rosa using the matK sequence: Molecular evidence for the narrow genetic background of modern roses. Scientia Hort. 77:73-82.

Matsumoto, S., M. Kouchi, and H. Fukui. 2000. Phylogenetic analyses of the subgenus Eurosa using the ITS nrDNA sequence. Acta Hort. 521:193-202.

Millan, T., F. Osuma, S. Cobos, A.M. Torres, and J.T. Cubero. 1996. Using RAPDs to study phylogenetic relationship in Rosa. Theor. Appl. Genet. 92:273-277.

Nauta, M. and F.J. Weissing. 1996. Constraints on allele size at microsatellite loci: Implications for genetic differentiation. Genetics 143:1021-1032.

Ortì, G., D.E. Pearse, and J. Avise. 1997. Phylogenetic assessment of length variation at a microsatellite locus. Proc. Natl. Acad. Sci. USA 94:10745-10749.

Paetkau, D., L.P. Waits, P.L. Clarkson, L. Craighead, and C. Strobeck. 1997. An empirical evaluation of genetic distance statistics using microsatellite data from bear (Ursidae) populations. Genetics 147:1943-1957.

Rajapakse, S., D.H. Byrne, L. Zhang, N. Anderson, K. Arumuganathan, and R.E. Ballard. 2001a. Two genetic linkage maps of tetraploid roses. Theor. Appl. Genet. 103:575-583.

Rajapakse, S., M. Hubbard, J.W. Kelly, A.G. Abbott, and R.E. Ballard. 1992. Identification of rose cultivars by restriction fragment length polymorphism. Scientia Hort. 52:237-245.

Rajapakse, S., L. Zhang, R.E. Ballard, and D.H. Byrne. 2001b. AFLP marker development in rose for genetic mapping: comparison of three restriction enzyme pairs. Acta Hort. 546:619-628.
Rehder, A. 1940. Manual of cultivated trees and shrubs. Macmillan, New York.

Smulders, M.J.M., Y. Noordijk, W. Rus-Kortekaas, G.M.M. Bredemeijer, and B. Vosman. 2003. Microsatellite genotyping of carnation varieties. Theor. Appl. Genet. 106:1191-1195.

Takeuchi, S., K. Nomura, H. Uchiyama, and K. Yoneda. 2000. Phylogenetic relationship in the genus Rosa based on the restriction enzyme analysis of the chloroplast DNA. J. Jpn. Soc. Hort. Sci. 69(5):598-604

Takezaki, N. and M. Nei. 1996. Genetic distances and reconstrution of phylogenetic trees from microsatellite DNA. Genetics 144:389-399.

Testolin, R., T. Marrazzo, G. Cipriani, R. Quarta, I. Verde, M.T. Dettori, M. Pancaldi, and S. Sansavini. 2000. Microsatellite DNA in peach (Prunus persica L. Batsch) and its use in fingerprinting and testing the genetic origin of cultivars. Genome 3(43):512-520.

Torres, A.M. 1993. Identifying rose cultivars using random amplified polymorphic DNA markers. HortScience 28(4):333-334.

Vainstein A. and H. Ben-Meir. 1994. DNA fingerprint analysis of roses. J. Amer. Soc. Hort. Sci. 119(59):1099-1103.

Vosman, B., D. Visser, J.R. van der Voort, M. J.M. Smulders, and F. van Eeuwijk. 2004. The establishment of 'essential derivation' among rose varieties, using AFLP. Theor. Appl. Genet. 109:1718-1725.

Wen, X.P., X.M. Pang, and X.X. Deng. 2004. Characterization of genetic relationships of Rosa roxburghii Tratt and its relatives using morphological traits, RAPD and AFLP markers. J. Hort. Sci. Biotechnol. 79(2):189-196

Wissemann, V. 2003. Conventional taxonomy of wild roses, p. 111-117. In: A. Roberts, T. Debener, and S. Gudin (eds.). Encyclopedia of rose science. Academic Press, London.

Wissemann, V. and C.M. Ritz. 2005. The genus Rosa (Rosoideae, Rosaceae) revisited: Molecular analysis of nrITS-1 and atpB-rbcL intergenic spacer (IGS) versus conventional taxonomy. Bot. J. Linnean Soc. 147:275-290.

Wu, S., Y. Ueda, H. He, S. Nishihara, and S. Matsumoto. 2000. Phylogenetic analysis of Japanese Rosa species using matK sequences. Breeding Sci. 50(4):275-281.

Wu, S., Y. Ueda, S. Nishihara, and S. Matsumoto. 2001. Phylogenetic analysis of Japanese Rosa species using DNA sequences of nuclear ribosomal internal transcribed spacers (ITS). J. Hort. Sci. Biotechnol. 76(2):127-132.

Yokoya, K., A.V. Roberts, J. Mottley, R. Lewis, and P.E. Brandham. 2000. Nuclear DNA amounts in roses. Ann. Bot. 85:557-561.

Zhang, D., C. Besse, M.Q. Cao, and M.H. Gandelin. 2001. Evaluation of AFLPs for variety identification in modern rose Rosa hybrida L. Acta Hort. 547:351-357. 